\title{
Reaktivní agilita před a po sportovně-specifickém rozcvičení u hráčů stolního tenisu
}

\section{The reactive agility of table-tennis players before and after sport-specific warm-up}

\author{
Pavel Vacenovský, Tomáš Vencúrik, Martin Sebera \\ Fakulta sportovních studii Masarykovy univerzity, Brno
}

\begin{abstract}
Abstrakt
Cílem studie bylo zjistit a porovnat reaktivní agilitu ligových hráčů a hráčů regionálních soutěží a její změny vlivem sportovně-specifického rozcvičení. Výzkumný soubor tvořilo 43 hráčů, kteři byli rozděleni do dvou skupin. Jednu skupinu tvořilo 22 hráčů z družstev hrající národní ligové soutěž $(24,3 \pm 5,6$ let, výška 179,4 $\pm 8 \mathrm{~cm}$, hmotnost 74,8 \pm 10,4kg), druhou skupinu 21 hráčů hrajících nižší regionální soutěže $(26,7 \pm 5,64$ let, výška 180,2 $\pm 7,7 \mathrm{~cm}$, hmotnost 77,8 $\pm 10,5 \mathrm{~kg})$.

Použili jsme Fitro agility test modifikovaný pro stolní tenis před a po rozcvičení. Pro analýzu dat byla použita dvoufaktorová ANOVA při opakovaných měřeních. Při porovnání reaktivní agility jsme zjistili signifikantní rozdil před a po sportovně-specifickém rozcvičení jak u skupiny ligových hráčů (885,94 $\pm 122,69$ ms před rozcvičením, $842,80 \pm 119,48$ ms po rozcvičení, zlepšení $04,87 \%, p<0,0004)$, tak u skupiny hráčů nižších soutěží $(932,96 \pm 114,78$ ms před rozcvičením, $871,90 \pm 119,68$ ms po rozcvičení, zlepšení o 6,54 \%, p <0,0002). I když ligový hráči dosáhli lepších výsledků, rozdíl mezi skupinami nebyl shledán signifikantní. Taktéž bylo zjištěno, že účinek sportovně-specifického rozcvičení není pro různé skupiny rozdilný. Sportovně-specifické rozcvičení (rozehrání) hraje důležitou roli pro zlepšení reaktivní agility a proto by nemělo být podceňováno.
\end{abstract}

\begin{abstract}
The aim of the study was to determine and compare the reactive agility league players and players of regional competitions and its changes due to sport-specific warm-up. The research sample consisted of 43 players, who were divided into two groups. First group consisted of 22 players from teams playing in the national league competitions $(24.3 \pm 5.6$ years, body height $179.4 \pm 8 \mathrm{~cm}$, body weight $74.8 \pm 10.4 \mathrm{~kg}$ ), the second group of 21 players playing lower regional competitions $(26.7 \pm 5.64$ years, body height $180.2 \pm 7.7 \mathrm{~cm}$, body weight $77.8 \pm 10.5 \mathrm{~kg}$ ). We used Fitro agility test modified for table tennis before and after warm-up. For data analysis was used two-way ANOVA with repeated measures. When comparing reactive agility, we found significant difference before and after the sport-specific warm-up for group of league players ( $885.94 \pm 122.69$ ms before the warm-up, $842.80 \pm 119.48 \mathrm{~ms}$ after the warm-up, an improvement of $4.87 \%, p<0.0004)$ and also for the group of players from lower competitions $(932.96 \pm 114.78 m$ s before the warm-up, $871.90 \pm 119.68 \mathrm{~ms}$ after the warm-up, an improvement of $6.54 \%, p<0.0002)$. Although league players achieved better results, the difference between the groups was found not significant. The nonsignificant statistic values for interaction indicates, that league players did not respond to the sport-specific warm-up differently than players from lower competitions. Sport-specific warm-up is important for improving the reactive agility and therefore should not be underestimated.
\end{abstract}

Klíčová slova: hráči ligových a regionálních soutěží, Fitro agility Check, interakce, rozehrání.

Key words: players of league and regional competitions, Fitro agility Check, interaction, warm-up. 


\section{ÚVOD}

Stolní tenis je často považován za nejrychlejší sportovní hru. Ne snad proto, že by míček dosahoval vyšší rychlosti v porovnání s jinými sporty. Spíše proto, že herní prostor a hrací plocha jsou relativně malé a tím pádem i míček putuje po kratší trajektorii. Hráč musí rychle a opakovaně reagovat na soupeřovy údery. Stolní tenis vyžaduje vysoké nároky na nervosvalové funkce a nutí hráče ve velice krátkých časových úsecích okamžitě reagovat na nové herní situace. Rychlost míčku a krátká vzdálenost, kterou překoná, poskytuje hráči minimum času na reakci a provedení úderu. Proto je stolní tenis zařazen do skupiny reakčních sportů podle Yoshidy et al. (1995). Při rychlosti, která může dosáhnout více než $97 \mathrm{~km} / \mathrm{h}$, hráči mají pouze zlomek sekundy na to, aby posoudili směr, rychlost, množství rotace míčku ze soupeřova úderu a přesunuli se do pozice a provedli zvolený úder (McAfee, 2009). Aby se hráč dostal do správné pozice, vychází ze střehové pozice. Vzhledem k rychlosti hry, být ve střehové pozici tak často, jak je jen možné, umožní hráči provádět čistější údery častěji než jeho soupeři (Seemiller \& Holowchak, 1997). Z tohoto důvodu rychlá reakce, rozhodnost, rychlý pohyb a koordinace, které jsou součástí agility, jsou velice důležité. Agilita bývá definována jako rapidní pohyb celého těla se změnami rychlosti nebo směru jako odpovědi na určitý stimulus (Sheppard \& Young, 2006). Pro zdůraznění důležitosti rozhodovací složky, na kterou navazuje určitý pohybový úkon, používají někteří autoři pojem reaktivní agilita. Tento termín pro naši práci přebíráme (Farrow et al., 2005, Gabbett \& Benton, 2009).

Rozcvičení je neoddělitelnou součástí každé tréninkové jednotky i předzápasového procesu a slouží k optimalizaci připravenosti na sportovní výkon. Mnozí poukazují, že základním účelem rozcvičení je zvýšení tělesné a svalové teploty, zvýšení pružnosti svalů a šlach, stimulace krevního oběhu k periferii a zkvalitnění pohybové koordinace (Smith,1994, Martens, 2004, Dovalil, 2002, Holienka, 2001). Mnoho současných studií se zaměřuje na rozdíly v efektu statického a dynamického strečinku. Studie Mcmilliana et al. (2006) poukazuje na zlepšení agility a síly po dynamickém strečinku. Amiri-Khorasani et al. (2010) zjistil, že dynamický strečink během rozcvičení byl nejvíce efektivní jako příprava na výkon, kde je hlavní složkou agilita. Van Gelder \& Bartz (2011) poukazují na skutečnost, že v porovnání se statickým strečinkem či žádným strečinkem, dynamický strečink významně zlepšuje výsledky testů zaměřené na uzavřené agility dovednosti. Podle Magnera et al. (2012) dynamické rozcvičení mělo větší dopad na jednoduchý výběrový reakční čas než statické rozcvičení. Dynamický strečink je podobný sportovně specifickému rozcvičení (vykonávají se při něm pohyby specifické pro danou sportovní aktivitu, avšak nižší intenzitou) (Nelson \& Kokkonnen, 2009).

Cílem našeho výzkumu bylo zjistit vliv sportovně-specifického rozcvičení hráčů stolního tenisu, jelikož jsme nenalezli žádnou studii, která by se této problematice věnovala, Zajímalo nás také, zda je rozdílný účinek takového rozcvičení u hráčů ligových soutěží a hráčů regionálních soutěží.

\section{METODIKA}

Naší studie se účastnilo 43 hráčů, které jsme rozdělili do dvou skupin. Dvacet dva hráčů patří do družstev hrající ligové soutěže v České republice (1.-3. liga). Hráči jsou ve věku 24,3 \pm 5,6 let, výšky $179,4 \pm 8 \mathrm{~cm}$ a hmotnosti $74,8 \pm 10,4 \mathrm{~kg}$. Druhou skupinu naproti tomu tvoří hráči regionálních soutěží (okresní úroveñ) věku 26,7 $\pm 5,64$ let, výšky 180,2 \pm 7,7 cm a hmotnosti 77,8 $\pm 10,5 \mathrm{~kg}$. Zařazení na soupisky družstev je mimo jiné podmíněno umístěním na žebřičcku, který je vytvořen na základě výsledků $\mathrm{v}$ předešlé sezóně.

Agility test měřený pomocí FiTRO Agility Check (FTVŠ UK, Bratislava) je detailně popsán v publikaci Zemková \& Hamar (2009) a byl použit pro mnoho sportovních her včetně raketových. Tento př́istroj generuje stimuly a měří celkový čas pohybu, ve kterém je už zahrnut i čas potřebný pro správné rozhodnutí. Proto je vhodný pro zjištování reaktivní agility. My jsme prováděli modifikovaný agility test pro stolní tenis vždy na začátku tréninku před rozcvičením (pre-test) a po specifickém rozcvičení (post-test) a to uprostřed herní sezóny. Hráči startovali ve vzdálenosti 
$0,75 \mathrm{~m}$ za stolem. Museli se co nejrychleji dotknout jedné ze čtyř ploch (vypínačů). Dva vypínače byly umístěny do rohů stolu (šiřka stolu $1,525 \mathrm{~m}$ ), další dva na zemi právě pod rohy stolu (viz obr. 1). Toto rozmístění zohledňuje specifické nároky pro stolní tenis. Hráči se dotýkali vypínačů v závislosti na lokalizaci vizuálního stimulu, který se objevoval v jednom z rohů obrazovky počítače. Testovaný, který hraje s raketou v pravé ruce, se měl dotknout vypínačů pravou nohou nebo pravou rukou (praváci pravou), leváci pak levou nohou (vypínače na zemi) nebo rukou (vypínače na stole). Test obsahoval 16 vizuálních stimulů (4 v každém směru) s náhodným výběrem lokalizace a fixním časem 2000 ms pro vygenerování. Výsledek testu je průměr časů pohybové reakce při použití ruky, nohy a celkový pohybově reakční čas.

Každý sportovec prováděl standardizované pětiminutové základní rozcvičení obsahující běh a prvky statického i dynamického protažení. Poté následovalo specifické herní rozcvičení (rozehrání) trvající 15 minut založené na základních herních cvičeních, které postupovali od jednodušších až k více komplexním. Jednalo se převážně o uzavřené herní kombinace pro forhendové a bekhendové kontra údery.

Pro zpracování výsledků byla použita základní popisná statistika a Shapiro-Wilk test pro distribuci normality. Pro porovnání dat byla provedena dvoufaktorová ANOVA při opakovaných měřeních. Jeden faktor A byly zvoleny pokusy (pre-test, post-test), faktor B pak skupiny (ligový, regionální hráči). Jako post hoc test vybrán Tukey’s HSD test. Hladina statistické významnosti byla stanovena na $\mathrm{p}<0,05$. Pro statistické výpočty byl použit program Statistica 12 (StatSoft Inc., Tulsa, USA).

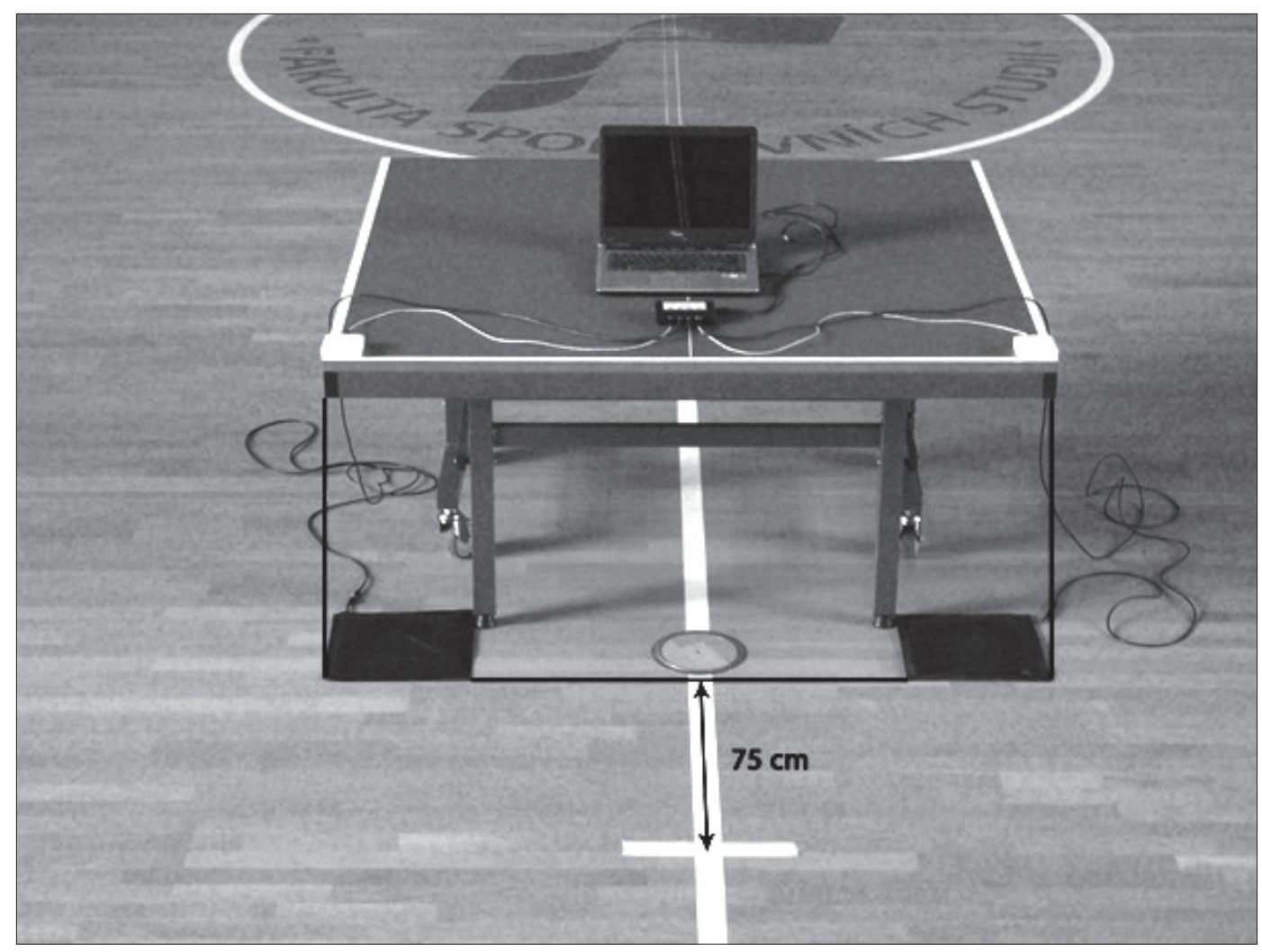

Obr. 1: Modifikovaný agility test pro stolní tenis 


\section{VÝSLEDKY}

Výsledky agility testu modifikovaného pro stolní tenis jsou představeny v tabulkách 1 a 2 , kde nalezneme hrubá data před a po specifickém rozcvičení, které jsme posléze analyzovali. Díky použitému př́stroji, jsme mohli využít i hodnoty, které hráči dosáhli po dotyku vypínačů pouze rukou (sloupce v tabulkách označené ruka) a pouze nohou (sloupce v tabulkách označené noha) Průměrný čas pohybové reakce před rozcvičením byl 885,94 1 122,69 ms (ligový hráči) a 932,96 $\pm 114,78 \mathrm{~ms}$ (regionální hráči). Po rozcvičení byla zjištěna průměrná hodnota $842,80 \pm 119,48$ ms u ligových hráčů a 871,90 119,68 ms u regionálních hráčů, což znamená zlepšení o 43.14 ms (4,87 \%), resp. 61,06 ms (6.54 \%). Obdobné zlepšení zaznamenali hráči obou skupin ve směrech, kdy se dotkli vypínače pouze rukou. Ligový hráči se zlepšili o $38,1 \mathrm{~ms}$ (4,42\%), regionální hráči o 69,52 ms (7,67 \%). Ve směrech, kdy se dotýkali podložky nohou, se ligový hráči zlepšili o 48,18 ms (5,3\%), regionální hráči o 52,61 ms (5,49\%).

Tabulka 1: Průměrné časy pohybové reakce v milisekundách dosažené hráči ligových soutěží (noha pouze po doteku podložek nohou, ruka - pouze po doteku vypínačů rukou)

\begin{tabular}{|c|c|c|c|c|c|c|}
\hline & \multicolumn{2}{|c|}{ Před rozcvičením } & \multicolumn{2}{c|}{ Po rozcvičení } & \\
\hline Hráč & noha & ruka & celkem & noha & ruka & celkem \\
\hline 1 & 881,625 & 815,75 & 848,6875 & 900,5 & 816,125 & 858,3125 \\
\hline 2 & 885,25 & 827,125 & 856,1875 & 851,75 & 745,875 & 798,8125 \\
\hline 3 & 916,875 & 892,875 & 904,875 & 888,125 & 848,625 & 868,375 \\
\hline 4 & 851,5 & 784,5 & 818 & 810,25 & 790,875 & 800,5625 \\
\hline 5 & 995,5 & 1033,75 & 1014,625 & 888,875 & 955,5 & 922,1875 \\
\hline 6 & 1003,75 & 902 & 952,875 & 925,875 & 826,875 & 876,375 \\
\hline 7 & 946,25 & 839,875 & 893,0625 & 854,5 & 878,625 & 866,5625 \\
\hline 8 & 787,125 & 772,125 & 779,625 & 776,75 & 736 & 756,375 \\
\hline 9 & 958,125 & 850 & 904,0625 & 923,75 & 818,75 & 871,25 \\
\hline 10 & 787,5 & 783,125 & 785,3125 & 781,625 & 789,875 & 785,75 \\
\hline 11 & 993,4 & 982,375 & 987,875 & 961,75 & 1007,875 & 984,8125 \\
\hline 12 & 967,625 & 971,375 & 969,5 & 884,625 & 877,25 & 880,9375 \\
\hline 13 & 929,525 & 885 & 907,25 & 817 & 775,375 & 796,1875 \\
\hline 14 & 823,875 & 799,25 & 811,5625 & 831,375 & 785,25 & 808,3125 \\
\hline 15 & 894 & 853,625 & 873,8125 & 806,375 & 739,5 & 772,9375 \\
\hline 16 & 1094,25 & 992 & 1043,125 & 1002,38 & 924,75 & 963,5625 \\
\hline 17 & 769,375 & 780,625 & 775 & 752,5 & 838,5 & 795,5 \\
\hline 18 & 903,625 & 876 & 889,8125 & 806,25 & 867,75 & 837 \\
\hline 19 & 983,125 & 960,625 & 971,875 & 1006,75 & 989,25 & 998 \\
\hline 20 & 878 & 816 & 847 & 872,625 & 791,125 & 831,875 \\
\hline 21 & 785 & 697,625 & 741,3125 & 702,375 & 576,5 & 639,4375 \\
\hline 22 & 963,15 & 867,375 & 915,25 & 892,5 & 764,625 & 828,5625 \\
\hline Všichni & $\mathbf{9 0 9 , 0 2 0 5}$ & $\mathbf{8 6 2 , 8 6 3 6}$ & $\mathbf{8 8 5 , 9 4 0 3}$ & $\mathbf{8 6 0 , 8 4 1}$ & $\mathbf{8 2 4 , 7 6 7 0}$ & $\mathbf{8 4 2 , 8 0 4}$ \\
Směr. odch. & $\mathbf{1 1 9 , 0 6}$ & $\mathbf{1 1 8 , 1 0}$ & $\mathbf{1 2 2 , 6 9}$ & $\mathbf{1 0 6 , 8 1}$ & $\mathbf{1 1 9 , 2 4}$ & $\mathbf{1 1 9 , 4 8}$ \\
\hline & & & & & & \\
\hline
\end{tabular}


Tabulka 2: Průměrné časy pohybové reakce v milisekundách dosažené hráči regionálních soutěží (noha - pouze po doteku podložek nohou, ruka - pouze po doteku vypínačů rukou)

\begin{tabular}{|c|c|c|c|c|c|c|}
\hline \multirow[b]{2}{*}{ Hráč } & \multicolumn{2}{|c|}{ Před rozcvičením } & \multirow[b]{2}{*}{ celkem } & \multicolumn{2}{|c|}{ Po rozcvičení } & \multirow[b]{2}{*}{ celkem } \\
\hline & noha & ruka & & noha & ruka & \\
\hline 1 & 1078,75 & 1011,625 & 1045,188 & 984,525 & 952,625 & 968,5625 \\
\hline 2 & 980,125 & 878,375 & 929,25 & 937,625 & 864,375 & 901 \\
\hline 3 & 830,75 & 783,875 & 807,3125 & 832,25 & 710,125 & 771,1875 \\
\hline 4 & 961,5 & 919,5 & 940,5 & 954,5 & 942,375 & 948,4375 \\
\hline 5 & 1038,9 & 971,625 & 1005,25 & 985,15 & 929,625 & 957,375 \\
\hline 6 & 983,5 & 911,125 & 947,3125 & 946,25 & 830,75 & 888,5 \\
\hline 7 & 973 & 862 & 917,5 & 881,25 & 869,375 & 875,3125 \\
\hline 8 & 900,5 & 832,5 & 866,5 & 900,5 & 763,75 & 832,125 \\
\hline 9 & 815,875 & 806,5 & 811,1875 & 780,875 & 676,75 & 728,8125 \\
\hline 10 & 1032,65 & 965,4 & 999 & 965,25 & 772,625 & 868,9375 \\
\hline 11 & 993,275 & 1074,9 & 1034,063 & 943 & 941,25 & 942,125 \\
\hline 12 & 882,75 & 927,875 & 905,3125 & 924,125 & 856,5 & 890,3125 \\
\hline 13 & 902,5 & 873,125 & 887,8125 & 965 & 773 & 869 \\
\hline 14 & 895,125 & 929,125 & 912,125 & 880,625 & 910,375 & 895,5 \\
\hline 15 & 995,25 & 883,5 & 939,375 & 939,275 & 924,875 & 932,0625 \\
\hline 16 & 999,625 & 954,125 & 976,875 & 962,75 & 780 & 871,375 \\
\hline 17 & 913,75 & 838 & 875,875 & 776,125 & 782,375 & 779,25 \\
\hline 18 & 1063,375 & 940,125 & 1001,75 & 959,625 & 815,125 & 887,375 \\
\hline 19 & 949,625 & 838,375 & 894 & 864,625 & 888,125 & 876,375 \\
\hline 20 & 962,875 & 889,25 & 926,0625 & 752,375 & 772,125 & 762,25 \\
\hline 21 & 984,275 & 955,5 & 969,875 & 897,5 & 830,375 & 863,9375 \\
\hline $\begin{array}{l}\text { V̌̌ichni } \\
\text { Směr. odch. }\end{array}$ & $\begin{array}{l}958,9512 \\
118,94\end{array}$ & $\begin{array}{l}906,9726 \\
104,51\end{array}$ & $\begin{array}{l}932,9583 \\
114,78\end{array}$ & $\begin{array}{l}906,3429 \\
118,22\end{array}$ & $\begin{array}{l}837,4524 \\
111,20\end{array}$ & $\begin{array}{l}871,8958 \\
119,68\end{array}$ \\
\hline
\end{tabular}

Pomocí faktové analýzy jsme zjistili následující: hlavní efekt faktoru A v testu celkové pohybové reakce (pokusy pre-test a post-test) $\mathrm{F}_{\mathrm{A}}=55,66, \mathrm{p}<0,0000$; hlavní efekt faktoru $\mathrm{F}_{\mathrm{B}}=3,14, \mathrm{p}<0,084$; hlavní efekt pro interakci $\mathrm{F}_{\mathrm{AB}}=1,71, \mathrm{p}<0,1987$. Pomocí další analýzy jsme zjistili i jednoduché efekty, které nám potvrdili statistickou významnost efektu rozcvičení u každé skupiny zvlášt. Pro skupinu ligových hráčů je hodnota $\mathrm{p}<0,0004$, u skupiny regionálních hráčů $\mathrm{p}<0,0002$. Stejně tak jednoduché efekty B potvrdili, že rozdíly mezi ligovými a regionálními nejsou statisticky významné (při pre-testu zjištěna hodnota $\mathrm{p}<0,1725$, při post-testu $\mathrm{p}<0,5738$ ). Interakce je kombinovaný efekt faktorů na závislé proměnné (Vincent, 1994). Z hodnot zjištěných pro interakci jsme nezjistili statisticky významný rozdíl. To znamená, že účinek rozcvičení je pro obě skupiny přibližně stejný a rozcvičení neovlivňuje významněji jednu nebo druhou skupinu. Výsledky jsou zaznamenány i pomocí grafu, kde jsou znázorněny spojnice průměrných hodnot před rozcvičením a po rozcvičení (obr. 2). Osa y je shodná pro obě skupiny a vyjadřuje čas v milisekundách, skupina A jsou ligový hráči, skupina B hráči regionálních soutěží.

Podobné výsledky jsme získali i při hodnocení časů dosažených rukou (hlavní efekt $\mathrm{F}_{\mathrm{A}}=33,41$, $\left.\mathrm{p}<0,0000, \mathrm{~F}_{\mathrm{B}}=1,45, \mathrm{p}<0,2357, \mathrm{~F}_{\mathrm{AB}}=2,85, \mathrm{p}<0,0991\right)$. Statistická významnost efektu rozcvičení byla potvrzena u obou výkonnostních skupin (ligový hráči $p<0,0274$, regionální $p<0,0002$ ). Při hodnocení časů dosažených nohou jsme zjistili hodnoty pro hlavní efekty $\mathrm{F}_{\mathrm{A}}=40,06, \mathrm{p}<0,0000$, $\mathrm{F}_{\mathrm{B}}=4,79, \mathrm{p}<0,0343, \mathrm{~F}_{\mathrm{AB}}=0,08, \mathrm{p}<0,7823$. Zde nás samozřejmě zaujala nízká hodnota $\mathrm{p} u$ hlavního efektu $\mathrm{B}$, ovšem další analýza nepotvrdila statisticky významné rozdíly mezi skupinami ani 
před rozcvičením, ani po rozcvičení. Opět však byla potvrzena statistická významnost efektu rozcvičení u obou skupin (ligový hráči $\mathrm{p}<0,0007$, regionální $\mathrm{p}<0,0004$ ).

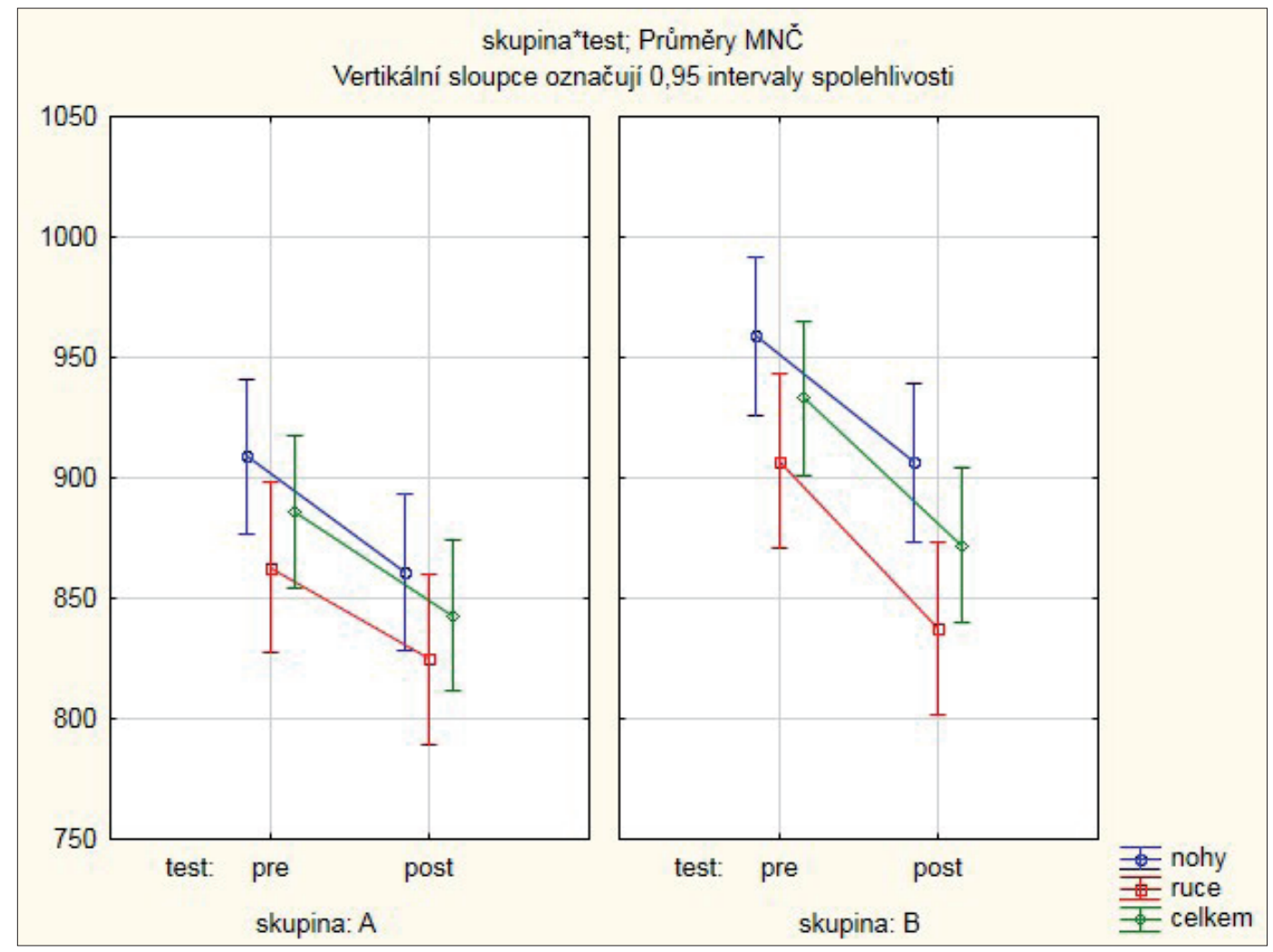

Obrázek 2:

Reaktivní agilita hráčů ligové (skupina A) a regionální (skupina B) úrovně před a po rozcvičení

\section{DISKUZE}

Tak jako v jiných sportovních hrách, i ve stolním tenisu existuje mnoho faktorů, které ovlivňují herní výkon hráče. Jelikož je stolní tenis hra velmi dynamická s náhlými změnami herních situací, považujeme reaktivní agilitu včetně rychlosti pohybové reakce za faktor velmi důležitý. To potvrzuje i studie Streškové (2002), která uvádí, že právě hráči stolního tenisu dosahují nejlepších reakčních časů v porovnání s ostatními sportovci. Ovlivňování hráčů prostřednictvím tréninku je dlouhodobý proces a studie Vidji et al. (2012) potvrdila, že čím déle hraje hráč stolní tenis, tím dosahuje lepších hodnot vizuálního reakčního času. Ovlivnění tohoto faktoru tedy přispívá k dosažení lepších výkonů a výsledků. Zde můžeme poukázat i na námi získané výsledky, kdy ligový hráči prokazovali vyšší úroveň reaktivní agility v porovnání s hráči regionálních soutěží, i když tyto výsledky nebyly shledány statisticky významnými. My jsme ale především chtěli zjistit vliv sportovně-specifického rozcvičení na reaktivní agilitu. Získané hodnoty dokazují významnost dosažených změn a jsou podpořeny množstvím studií zmíněných v úvodu. Zůstává otázkou, zda jiné dynamické rozcvičení by mělo rozdílný efekt, jelikož Gabbett et al. (2008) nezjistil významný rozdíl pro rychlost, rychlost se změnou směru a reaktivní agilitu při porovnávání dvou rozdílných dynamických rozcviček - jedna obsahovala pouze uzavřené dovednosti, ve druhé se objevily také dovednosti otevřené. Dále jsme zjistili, že rozdíl v časech před a po rozcvičení je o málo vyšší pro skupinu hráčů regionální úrovně, přesto tento rozdíl není významný. Jen to dotvrzuje důležitost rozcvičení na herní výkon a dokládá přijatelnost této formy rozcvičení pro všechny výkonnostní 
úrovně. Ostatně zařazení dynamických sportovně-specifických aktivit doporučuje též Chaouachi et al. (2010).

\section{ZÁVĚR}

Tréninkový proces je dlouhodobá záležitost, která má primární podíl na zlepšení výkonnosti včetně reaktivní agility. Zlepšení reaktivní agility lze dosáhnout i v den tréninku či utkání, pokud se provádí rozcvičení efektivně. Studie potvrdila statisticky významné zlepšení reaktivní agility pomocí převážně herního rozcvičení. Hráči by neměli rozehrání před zápasem podceňovat, přijít $\mathrm{s}$ časovým předstihem a řádně se připravit, což není v nižších soutěžích pravidlem. Odezva rozcvičení hráčů regionální úrovně je v současnosti obdobná než u hráčů vyšší výkonnostní úrovně.

Na základě svých poznatků doporučujeme sportovně-specifické rozcvičení ve stolním tenise pro jeho efekt na reaktivní agilitu.

\section{Literatura}

Amiri-Khorasani, M., Sahebozamani, M., Tabrizi, K. G., \& Yusof, A. B. (2010). Acute effect of different stretching methods on Illinois agility test in soccer players. The Journal of Strength \& Conditioning Research, 24(10), 2698-2704.

Dovalil, J. (2002). Výkon a trénink ve sportu. Praha: Olympia.

Farrow, D., Young, W., \& Bruce, L. (2005). The development of a test of reactive agility for netball: a new methodology. Journal of Science and Medicine in Sport, 8(1), 52-60.

Gabbett, T., \& Benton, D. (2009). Reactive agility of rugby league players.Journal of Science and Medicine in Sport, 12(1), 212-214.

Gabbett, T. J., Sheppard, J. M., Pritchard-Peschek, K. R., Leveritt, M. D., \& Aldred, M. J. (2008). Influence of closed skill and open skill warm-ups on the performance of speed, change of direction speed, vertical jump, and reactive agility in team sport athletes. The Journal of Strength \& Conditioning Research, 22(5), 1413-1415.

Holienka, M. (2001). Rozcvičenie vo futbale. Bratislava: Slovenský futbalový zväz,

Chaouachi, A., Castagna, C., Chtara, M., Brughelli, M., Turki, O., Galy, O., .. \& Behm, D. G. (2010). Effect of warm-ups involving static or dynamic stretching on agility, sprinting, and jumping performance in trained individuals. The Journal of Strength \& Conditioning Research, 24(8), 2001-2011.

Magner, A., Chatham, K., Spradley, B., Wiriyapinit, S., Price, W., \& Akins, T. (2012). Static Stretching versus Dynamic Warm Up: The Effect on Choice Reaction Time as Measured by the Makoto Arena II. The Sport Journal, 15(1). Retrieved from: http://thesportjournal.org/article/static-stretching-versus-dynamic-warm-up-the-effect-on-choice-reaction-time-asmeasured-by-the-makoto-arena-ii/

Martens, R. (2004). Successful coaching. Champaign, Ill.: Human Kinetics.

McAfee, R. (2009). Table tennis: steps to success. Champaign, Ill.: Human Kinetics.

McMillian, D. J., Moore, J. H., Hatler, B. S., \& Taylor, D. C. (2006). Dynamic vs. static-stretching warm up: the effect on power and agility performance. The Journal of Strength \& Conditioning Research, 20(3), 492-499.

Nelson, A. G., \& Kokkonen, J. (2009). Strečink na anatomických základech. Praha: Grada.

Seemiller, D., \& Holowchak, M. (1997). Winning table tennis. Champaign, IL: Human Kinetics.

Sheppard, J. M., \& Young, W. B. (2006). Agility literature review: classifications, training and testing. Journal of Sports Sciences, 24(9), 919-932.

Smith, C. A. (1994). The warm-up procedure: to stretch or not to stretch. A brief review. Journal of Orthopaedic \& Sports Physical Therapy, 19(1), 12-17.

Strešková, E. (2002). Prínos zistovania disjunktívných reakčno-rýchlostných schopností v stolnom tenise. Acta Facultatis Educationis Physicae Universitatis Comenianae, 43, 147-151

Van Gelder, L. H., \& Bartz, S. D. (2011). The effect of acute stretching on agility performance. The Journal of Strength \& Conditioning Research, 25(11), 3014-3021.

Vincent, W. (1994). Statistics in kinesiology. Champaign, IL: Human Kinetics.

Vidja, K., Dodhia, S., Bhabhor, M., Bhanderi,P. Chudasama, J \& Jani, H. (2012). Long Term Playing of Table Tennis Improve the Visual Reaction Time. International Journal of Scientific Research, 1(6), Retrieved from http://theglobaljournals.com/ ijsr/file.php?val=November2012_1351879746_f0e2a_54.pdf

Yoshida K., Hiruta, S., Shimaoka, M., K., F., Ilmoto, Y., \& Yuza, N. (1995). A study on spin control techniques for chop and float services in table tennis. Proceedings FISU/CESU Conference: The 18th Universiade 1995 Fukuoka, Japan

Zemková, E., \& Hamar, D. (2009). Toward an understanding of agility performance. Boskovice: Albert. 